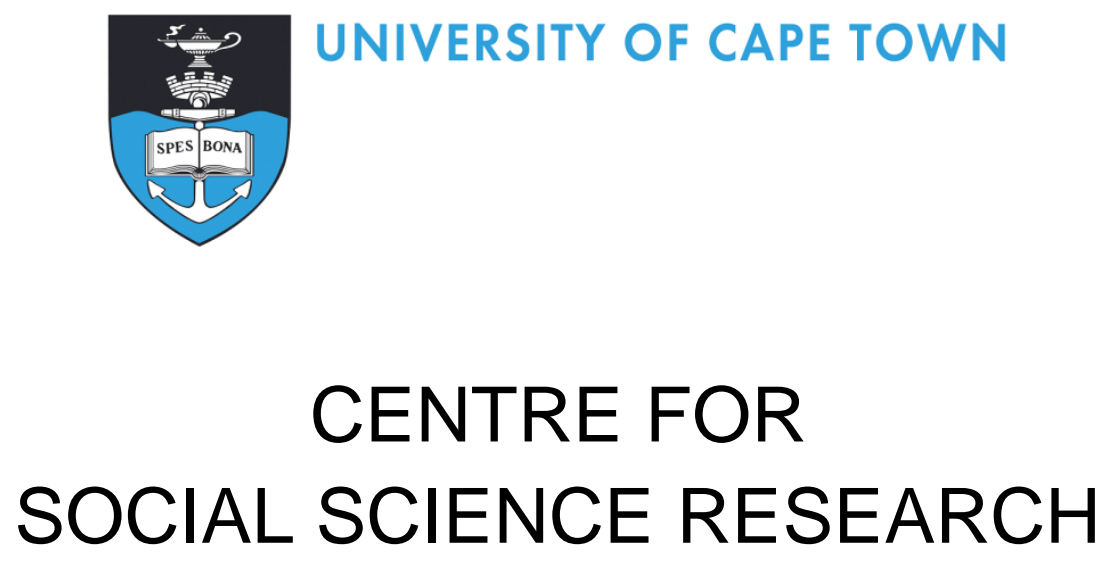

\title{
South Africa's system of dispute resolution forums: The role of the family and the state in customary marriage dissolution
}

Kirsty Button

CSSR Working Paper No. 339

July 2014

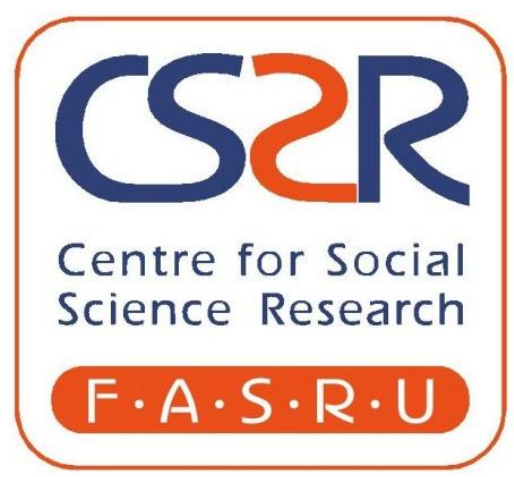



Published by the Centre for Social Science Research University of Cape Town 2014

http://www.cssr.uct.ac.za

This Working Paper can be downloaded from:

http://cssr.uct.ac.za/pub/wp/339/

ISBN 978-1-77011-326-8

(C) Centre for Social Science Research, UCT, 2014

About the author:

Kirsty Button graduated from UCT with a BSocSci Honours in Sociology in 2013. She is currently undertaking her Masters in Sociology, also at UCT.

Acknowledgements:

The author would like to thank Prof. Chuma Himonga, head of the National Research Foundation Chair in Customary Law at the University of Cape Town, for permitting access to and the use of the data upon which this paper is based.

This paper has benefitted considerably from the comments, suggestions and advice of Dr. Elena Moore, whose guidance and support has been invaluable in the writing process of this paper. 


\section{South Africa's system of dispute resolution forums: The role of the family and the state in customary marriage dissolution}

\section{Abstract}

In being a legal pluralist state, South Africa has a system of state and customary dispute resolution forums. This paper is concerned with this system of dispute resolution forums, particularly in how marital disputes relating to the dissolution of customary marriages are mediated and resolved. It is demonstrated, through drawing upon data collected for the purposes of a larger research project, that there are serious shortcomings which exist within this system. Such shortcomings include the operation of structural constraints which limit women in their ability to access state dispute resolution forums for support in marital breakdown and the availability of some customary dispute resolution forums which appear to be under-utilised by couples experiencing marital breakdown. Another possible shortcoming within the abovementioned system is the insufficient assistance that is offered by the state, to married couples experiencing marital conflict and breakdown. This paper argues that these shortcomings prevent equitable outcomes in marital conflict and breakdown from being reached. Consequently, such shortcomings contribute to women being rendered economically vulnerable upon the dissolution of their customary marriages as they are often left to deal with marital conflict and breakdown in the context of unequal power relations which exist between spouses. This paper concludes by discussing possible solutions that could be adopted to rectify the shortcomings and help ensure that gender equality is achieved upon the dissolution of customary marriages.

\section{Introduction}

South Africa is a legal pluralist state in that both state and African customary law have legal force (Bennett, 2004). These bodies of law have conventional forums of dispute resolution, which were recognised by the Recognition of Customary Marriages Act 120 of 1998 (RCMA). Thus, there exists a system of 
both customary and state dispute resolution forums which can be approached for assistance with the mediation or resolution of marital conflicts. This paper is concerned with this particular system of dispute resolution forums and more specifically with how disputes relating to the dissolution of customary marriages are mediated and resolved.

The RCMA was enacted with the objective of ensuring gender equality within customary marriages (Mbatha, 2005). Furthermore, the Act envisaged the state judicial system as being a forum of dispute resolution that could ensure gender equality upon the dissolution of customary marriages (Mbatha et al., 2007). However, many scholars have argued that these objectives are not being achieved in practice (Mamashela and Xaba, 2003; Higgins et al., 2007; Monareng and Zounmenou, 2007).

The main objective of this paper is to highlight that gender equality is not being achieved upon the dissolution of many customary marriages because there are serious shortcomings which exist within the abovementioned system. These shortcomings are contributing to a particular group of rural women being left economically vulnerable upon the dissolution of their customary marriages. It will be argued that unless addressed, these shortcomings will continue to hamper the achievement of gender equality following the dissolution of customary marriages.

In order to inform the above argument, this paper will discuss both past and current legislation which has had an impact on the forums of dispute resolution in South Africa. It will be demonstrated that the Black Administration Act of 1927 limited women in their ability to access state courts for assistance and protection in marital conflict. Furthermore, the operation of these provisions made women, who were married under customary law, susceptible to economic hardship in the event of marital breakdown. Following this, a more detailed account of the RCMA will be provided in order to highlight how the state is offering assistance to married couples who experience marital breakdown. This assistance, which is provided through state dispute resolution forums, is intended to help women obtain equitable outcomes in conflicts associated with the exit from their customary marriages. It has frequently been argued that there are problems with both state and customary dispute resolution forums, which prevent equitable outcomes in these conflicts from being achieved. Thus, following the above, this paper will discuss some of the critiques that have been levelled at both state and customary dispute resolution forums.

The subsequent sections of this paper will discuss the findings drawn from the data collected from both married and 'divorced' rural women. This data was collected for the purposes of a larger research project conducted by the National 
Research Foundation Chair in Customary Law. It will be shown that the married respondents held normative perceptions on how the system of dispute resolution forums should be navigated when dealing with marital conflict and breakdown in customary marriages. Furthermore, the findings from the 'divorcees' will highlight how this system was used in practice, when they experienced the dissolution of their customary marriages. It will be argued that as a consequence of these practices, the majority of the 'divorcees' were left in economically vulnerable positions following the dissolution of their customary marriages. By comparing the married respondents' perceptions with the practices of the women who underwent the dissolution of their marriages, the shortcomings which are present within the system of dispute resolution forums become apparent. In light of these shortcomings and the consequences for some rural women, this paper goes on to question whether the state is doing enough to ensure that the right to gender equality is being realised following the dissolution of customary marriages. This paper concludes with possible solutions that could be adopted to remedy the deficiencies within this system.

\section{Marital breakdown and dispute resolution forums during colonial and apartheid periods}

The Black Administration Act 38 of 1927 was introduced by colonial authorities and remained in force during the Apartheid period (Deveaux, 2003). It was claimed that the Act provided a more consistent approach to customary law and customary marriages (Deveaux, 2003).

The Act drew a distinction between 'civil marriages' and 'customary unions'. While the former were fully recognised under common law, the latter were not (Mamashela and Xaba, 2003). This meant that customary unions where not recognised as being fully legitimate and the sanctity of such unions were not protected by law. Customary unions were nullified upon the entry into a subsequent civil marriage. Similarly, customary unions entered into after the conclusion of a civil marriage were also void. Unlike those in civil marriages, customary union spouses did not, upon the dissolution of a customary union, have access to the full range of common law maintenance and support remedies (Mbatha et al., 2007). Lastly, as customary unions were not recognised by the state, a national register of customary unions did not exist to provide official verification of the existence of such unions (Posel, 1995).

It is also important to note that the customary law that was codified in the Act was designed to secure the loyalty of traditional leaders to governmental authorities, in order to ensure their cooperation in the regulation of the rural 
areas. The Act did so by protecting and increasing male authority in African communities. However, in bolstering patriarchal authority, the Act contributed to the further subordination of African women (Deveaux, 2003).

The abovementioned Act gave customary union husbands absolute ownership of household property, which included the personal property and earnings of their wives. The Act also rendered women perpetual minors under the guardianship of either their male relatives or husbands. The status of perpetual minority accorded to married women meant that they could neither acquire or alienate property, nor enter into contracts or litigate without the consent of or assistance from their husbands (Mamashela and Xaba, 2003).

Women married under customary law had access to traditional dispute resolution forums, which they could utilise to raise grievances about their marital relationships. Such dispute resolution forums were those recognised under customary law and included ward, headmen and chief's courts. However, custom dictated that women be represented by a male relative or guardian when raising grievances within these forums (Higgins et al., 2007). The migrant labour system, which was established during the colonial period and entrenched during apartheid, resulted in many men working away from their families that lived in rural areas (Marais, 2011). This limited rural women in their ability to be represented by male relatives in disputes with their husbands. The autonomy that married women had in raising grievances against their husbands would have been further hampered if their husbands were acting as their representatives within these forums.

The aforementioned provisions of the Black Administration Act limited women's access to state dispute resolution forums when seeking support for marital conflict. The status of perpetual minority made it difficult for women who were unhappy with their marriages to obtain relief from state courts. As a consequence, married African women could not, without the assistance of their spouses, access the state judicial system in order to enforce any remedies under customary law against their husbands (Mbatha et al., 2007).

The provisions of the Black Administration Act also served to prejudice women when marital conflicts could not be resolved and marital breakdown consequently ensued. According to evidence, marital breakdown in customary unions rarely resulted in divorce (Mbatha et al., 2007). Many scholars argued that there was a far greater incidence of rural married women being deserted by their husbands, who often established new families with other women (Burman, 1987). Desertion was made easy through the limited recognition and protection that was afforded to customary unions by the Black Administration Act as well as the lack of national customary union register. If in a customary union, men 
could enter into a subsequent civil marriage without formally divorcing their existing wives. Any customary union entered into previously would automatically be nullified in this way. The absence of a national customary union register made it difficult to verify the existence of customary unions which had been nullified in the above manner.

The practice of desertion had detrimental consequences for women. When women were deserted in the abovementioned way, they had little control over how or when their marriages ended. Furthermore, due to the Black Administration Act, customary unions were not regulated or protected by the state. This, in addition to their legal minority statuses, made it difficult for women to query the nullification of their marriages or obtain financial relief from state courts (Mbatha et al., 2007). Consequently, deserted women were left in economically vulnerable positions upon the dissolution of their marriages as their personal and matrimonial property accrued to their husbands and they were without legal means to protect themselves from the consequences of desertion.

It is clear that the provisions in the Black Administration Act rendered it difficult for women, married under customary law, to obtain assistance from state courts when undergoing the dissolution of their unions. Moreover, these provisions made rendered women, who were married in customary unions, susceptible to economic hardship in the event of desertion or divorce.

\section{The introduction of the RCMA}

The 1996 Constitution provided full legal recognition to customary law (Deveaux, 2003). However, such laws are only valid to the extent that they are consistent with the values and principles enshrined within the Constitution (Deveaux, 2003).

Many legal scholars were critical of the prejudicial consequences which flowed from the partial legal status of customary unions (Nhlapo, 1995). It was argued that the patriarchal customary marriage laws went against the constitutional value of gender equality. Consequently, the RCMA was promulgated in order to bring customary marriage laws in line with the values and rights enshrined within the Constitution (Mbatha, 2005). One of the main objectives of the RCMA was to prevent the economic vulnerability that women were exposed to upon the dissolution of their marriages (Mbatha, 2005).

All customary marriages concluded before and after the promulgation of the RCMA have been accorded full legal recognition by the Act (Mamashela and Xaba, 2003). Thus, these marriages are now recognised and protected by law and in state courts. The attribution of full legal status to customary marriages has 
meant that spouses married under customary law have available to them the full range of common law remedies for maintenance and support from state courts, should their customary marriages end (Himonga, 2007). The RCMA required that customary marriages be registered within three months of their entry and celebration. Such marriages are not nullified in the event of non-registration. However, registration does provide official proof of the existence of the customary marriage (Bennett, 2004). Official proof of the marriage is useful when attempting to exercise rights with regards to the matrimonial property or to obtain common law maintenance and support remedies from state courts in the event of marital breakdown.

In order to advance the status and rights of women in customary marriages and make customary marriage relationships more equitable, the RCMA repealed certain provisions of the Black Administration Act (Mamashela and Xaba, 2003). The perpetual minority status of women was abolished. Thus, in addition to not being under the perpetual guardianship of their husbands, married women now have full legal capacity under customary law to acquire and dispose of assets, enter into contracts and litigate in their own names. Furthermore, the Act aimed to introduce equality between spouses by giving them equal rights and statuses in customary marriages (Mamashela and Xaba, 2003).

The RCMA aimed to improve the economic position of women upon dissolution of their customary marriages. Customary marriages were made subject to common law matrimonial property regimes. All customary marriages are in community of property unless spouses conclude an anti-nuptial contract. These reforms have meant that spouses married under customary law jointly own and have equal powers of administration over all property acquired before and during the marriage. Thus, these provisions provided women with rights, which they previously did not have, to matrimonial property upon the dissolution of their customary marriages (Himonga, 2005).

As described in the previous section, many of the hardships faced by women in customary marriages stemmed from the economic vulnerabilities which were created by the prejudicial divorce and desertion practices. These hardships were aggravated by the difficulties women faced in accessing state courts for protection as well as the lack of support offered by the state to spouses in customary unions. The RCMA envisaged the state courts as forums for dispute resolution which would ensure equitable and fair outcomes in matters relating to the exit from a customary marriage (Mbatha et al., 2007). Decrees of divorce for customary marriages can be granted by regional courts. This has the aim of securing the economic rights of women married in terms of customary law, as the courts are able to enforce an equitable division of property and make orders for spousal and child maintenance. Through these provisions, state courts have 
been tasked with the responsibility of protecting the interests of women and children upon the dissolution of customary marriages and ensuring that the right to gender equality is achieved (Himonga, 2005). It is important to note that through these RCMA provisions the state can offer assistance in resolving marital conflict through the judicial system at the point of exit from a customary marriage.

\section{Legal pluralism and dispute resolution forums}

As the 1996 Constitution recognised the application of and adherence to customary law, South Africa came to be described as a legal pluralist state. Through such recognition, individuals who live under customary law are simultaneously subject to customary and state law (Bennett, 2004). Furthermore, they have the ability to utilise both state and customary forums of dispute resolution when seeking assistance with marital disputes (Higgins et al., 2007), as was recognised in the RCMA. The RCMA envisaged the state judicial system as being the forum to assist in the resolution of marital conflicts at the point of exit from customary marriages. However, the Act also stated that traditional leaders and others authorised under customary law are able to mediate marital disputes in customary marriages prior to the dissolution of such marriages in state courts (Higgins et al., 2007).

In being able to utilise both state and customary forums of dispute resolution, it has been argued that people in legal pluralist societies have the ability to navigate between different forums to obtain outcomes which are best suited to their interests (Griffiths, 1997). It can be perceived as beneficial to rural women, in legal pluralist contexts, to have multiple forums of dispute resolution, which can be turned to for assistance in the event of a marital dispute. Each forum of dispute resolution can be considered as a means of support for married couples, and married women in particular, who seek mediation of their martial disputes. When one forum fails to provide a satisfactory outcome to the dispute in question, another forum of dispute resolution can (hypothetically) be approached for assistance. This can be particularly important for rural women who experience marital conflict in the context of unequal power relationships within their marriages. As discussed in the preceding sections, a lack of accessible and adequate dispute resolution forums under the Black Administration Act contributed to the economic vulnerability that women experienced upon the exit from their customary marriages. Such women often had to negotiate this process by themselves. Due to the unequal power relations between married spouses, which were deepened through the Black Administration Act, the outcomes of such negotiations were often highly prejudicial to women. Thus, in having multiple accessible forums of dispute resolution, the risk of women suffering 
such prejudice following the dissolution of their marriages, particularly in the context of unequal power relationship between spouses, is reduced.

It has been argued that, among people who live in legal pluralist contexts, there is a normative sequence in which customary and state dispute resolution forums are turned to, when seeking assistance with the resolution of marital disputes (Griffiths, 1997; Higgins et al., 2007).

The research presented by Higgins et al. (2007) illustrated this point. Through their research in South Africa, they found that the majority of disputes arising from customary marriages were first dealt with within the family and failing that, within other traditional dispute resolution forums. The failure to obtain a resolution within the family often prompted the assistance of traditional headmen in a more public dispute resolution forum. Within these forums, headmen would often seek to resolve the dispute with the help of advisors or members from the broader community. If a marital conflict could not be resolved within this forum, people would sometimes transfer their disputes to chiefs' courts for resolution. It is argued that these traditional dispute resolution forums emphasise reconciliation between the married spouses concerned (Higgins et al., 2007). However, the authors noted that if marital disputes were not resolved and married spouses were not reconciled within these forums, parties would sometimes look to state courts for assistance.

It has been noted that the same progression of dispute resolution forums were used by women in rural areas of Botswana (Griffiths, 1997). Griffiths (1997) investigated how women in Botswana pursued claims against their male partners relating to compensation for pregnancy, maintenance and property rights. These claims were pursued in a legal pluralist context in which both customary and state law, as well as their associated dispute resolution forums, were recognised. It was further argued that within rural communities people had a tendency to favour resolution or mediation of marital disputes within traditional dispute resolution forums. However, in South Africa, the failure to obtain satisfactory outcomes within these forums often prompted women to turn to state courts for assistance. Thus, such research highlighted that when women failed to obtain satisfactory outcomes in one forum, they sought to rectify the situation by transferring their marital dispute to another forum (Griffiths, 1997).

It has frequently been acknowledged that there are problems with both state and traditional dispute resolution forums. Higgins et al. (2007) noted that although family and other traditional dispute resolution forums were frequently used by spouses in customary marriages, they often undermined the power of women. For instance, they argued that women were generally not permitted to speak or represent themselves in traditional dispute resolution forums., Their research 
further suggested that traditional leaders placed an emphasis on reconciliation rather than advocating for divorce upon the breakdown of customary marriages. They found that some traditional leaders would rather advise a married man to leave his current wife and establish a new home with another woman and then reconcile with his existing wife at a later stage, than initiate divorce proceedings (Higgins et al., 2007). Such advice is problematic in that it may not result in equitable outcomes in practice. For instance, existing wives in these situations may experience economic hardship as household income could be diverted from existing households to new households, leaving some women and children without means of financial support.

As will be highlighted in the following section, many women married under customary law have a high awareness of the protection that state courts can provide to them. However, research has shown that despite the promulgation of the RCMA, few customary marriages have reached state courts for dissolution (Mamashela and Xaba, 2003; Higgins et al., 2007). This raises questions about the accessibility of state courts and the possible structural constraints which may be preventing women from turning to them for assistance with their marital disputes.

Banda (2006) highlighted the existence of structural constraints which limit the ability of women to exercise their legal rights by accessing state dispute resolution forums. Referring to the provision of human rights to women in Southern Africa, Banda (2006) argued that these structural constraints have, for the most part, rendered only traditional dispute resolution forums available to women in customary marriages. These structural constraints will be further elaborated upon below.

Mamashela and Xaba (2003), Higgins et al. (2007) and Monareng and Zounmenou (2007) conducted research with women in various customary communities after the introduction of the RCMA. They all found that women within these communities lacked knowledge about the RCMA and the rights it gave them. These authors argued that this has constrained women in their abilities to draw upon state courts for assistance when exiting out of their customary marriages.

Prior to 2010, all divorces flowing from customary marriages were required to be granted by High Courts or Family Courts (Sloth-Nielsen, 2010). Himonga (2005) criticised this for constraining women in their ability to draw upon the provisions of the RCMA in state courts when undergoing the dissolution of their customary marriages. In order to benefit from the RCMA's provisions relating to the equitable distribution of matrimonial property upon divorce, women have had to be able to afford the expensive court and legal aid fees associated with 
litigation in these courts. However, it was argued that most women were unable to afford these fees which made access to the upper court system very difficult (Himonga, 2005). Since the promulgation of the Amendment of the Jurisdiction of the Regional Courts Act in 2010, regional courts have been able to issue decrees of divorce for customary marriages (Sloth-Nielsen, 2010). This went a long way in improving access to justice in the dissolution of customary marriages. However, it could still be argued that many women will still not be able to afford to have their customary marriages dissolved in regional courts, thereby limiting the application of the RCMA and the use of state courts in the dissolution of customary marriages.

Mamashela and Xaba (2003) explored the practical effects of the RCMA in rural KwaZulu-Natal communities. They sought to understand whether the RCMA had made any difference to the material positions of rural women upon dissolution of their customary marriages. Their research showed how the unequal power relations between spouses prevented women from negotiating for the application of the RCMA when their marriages ended. They found that since the promulgation of the RCMA, very few customary divorces had been heard by the upper courts in the area. This was not to say that there was an absence of marital breakdown in these rural areas. Instead, the authors argued that husbands simply deserted their wives rather than formally divorcing them within a state court, thus making the use of the RCMA provisions impossible. Women were argued to have had little control over such desertion as it was initiated through the discretion of their husbands, who simply left them without further notice. When deserted in this way, women thus lacked the power to control the terms upon which their marriages ended. Additionally, they lacked the ability to ensure that the dissolution of their marriages be regulated by state courts and the RCMA.

\section{Methodology}

This paper discusses the findings that were drawn from data collected for the purposes of a larger qualitative research project that was conducted by the National Research Foundation Chair in Customary Law, under the leadership of Himonga and Moore (2013). It aimed to investigate the impact which the RCMA had on those living under customary law. This study was conducted in six of South Africa's provinces, namely: Eastern Cape, Kwazulu-Natal, Mpumalanga, Limpopo, North West and Gauteng (Himonga and Moore, 2013). The first five of these provinces were selected on the basis that they contained large settled, rural communities living under customary law. Gauteng was selected on the basis that it contained peri-urban areas, which represented an intersection of both rural and urban communities. 
The data that is drawn upon in this paper was collected through semi-structured interviews with ordinary people who had married under customary law and/or had experienced the dissolution of their customary marriages. Given that this study aimed to evaluate the impact of the RCMA, which came into effect in 2000 , respondents were selected on the basis that they had been married or experienced the dissolution of their customary marriages after 2000 (Himonga and Moore, 2013).

This paper draws upon the findings from the initial interviews with 39 married respondents and 17 'divorced' respondents. Although all experienced the dissolution of their customary marriages, not all of the 'divorcees' were legally divorced. However, these respondents self-identified themselves as divorced and thus, this description is used to refer to them throughout this paper. The majority of both the married and divorced respondents were women, who varied between the ages of 30 and 50. Furthermore, two thirds of the married respondents and just over half of the divorced respondents were employed. These women were all concentrated in low-skilled, low-income occupations in the formal and informal sectors. Moreover, the majority of both these sets of respondents had registered their customary marriages, as was required by the RCMA (Himonga and Moore, 2013).

The semi-structured interviews aimed to gain an insight into how the married and divorced respondents experienced the entry into their marriages. For instance, the respondents were asked about their experiences in relation to the negotiation and transfer of lobolo and the marriage registration procedures. Additionally, the interviews conducted with the divorcees aimed to understand their experiences relating to the dissolution of their customary marriages (Himonga and Moore, 2013).

During their initial interviews, both the married and divorced respondents were presented with an identical set of written vignettes (Himonga and Moore, 2013). Written vignettes can be defined as stimuli, presented in the form of contextualised situations, to which respondents are asked to respond (Finch, 1987). The vignettes used in the abovementioned research project presented respondents with situations that revolved around fictitious characters who faced conflicts associated with their marital relationships. These conflicts stemmed from the differences between reformed customary marriage laws, as contained in the RCMA, and traditional practices, on specific matters (Himonga and Moore, 2013). In responding to the vignettes, the research participants were asked to advise the vignette characters on what they thought the right course of action would be in each situation. Thus, the vignettes investigated the perceptions and not the practices of the respondents (Finch, 1987). The 
responses to the vignettes offered an insight into the perceptions of the respondents regarding the RCMA as well as state and customary dispute resolution forums (Himonga and Moore, 2013).

Follow-up interviews were conducted with 5 of the married respondents from the Eastern Cape. These interviews aimed to gain more insight into the respondents' perceptions regarding the various dispute resolution forums and how they were perceived to be utilised in marital conflict.

The following two sections will discuss the findings from both the married and divorced respondents. The first section will discuss the findings from the married respondents. Their responses to three of the abovementioned vignettes will be discussed. These three vignettes specifically explored the respondents' perceptions on both state and customary dispute resolution forums in relation to marital conflict within and upon exit from customary marriages. The findings drawn from these vignettes are discussed as they offer insight to respondents' perceptions relating to how the system of dispute resolution forums should be used in marital conflict and breakdown in customary marriage. The findings from the follow-up interviews will also be discussed, as they elaborate upon the perceptions of the married respondents regarding the abovementioned system of dispute resolution forums. The second section will discuss the experiences of the divorced respondents. These findings highlight which dispute resolution forums were turned to by women who experienced the dissolution of their customary marriages. Thus, such findings shed light on how the system of dispute resolution forums was used in practice when marital breakdown in customary marriages occurred.

\section{Perceptions regarding forums for marital dispute resolution}

In discussing the married respondents' perceptions about the system of dispute resolution forums, this section first elaborates upon their perceptions about customary forums of dispute resolution. Following this, their perceptions about state and other forums of dispute resolution are discussed.

\section{Family as a forum for dispute resolution: an emphasis on reconciliation}

During their initial interviews, the married respondents were presented with a vignette which explored their perceptions regarding the importance of lobolo when entering into customary marriage. 33 out of the 39 married respondents 
reflected the perception that lobolo should be negotiated and transferred in customary marriages. These findings indicate that the married respondents held normative beliefs about the importance of the lobolo in customary marriage. However, one of the functions of lobolo is of particular relevance to the arguments made in this paper.

The negotiation and transfer of lobolo was believed to join two families. In so doing, this was perceived to facilitate the recognition of each spouse as legitimately being part of the families of their respective 'in-laws'. This point was elaborated upon in the follow-up interviews: 'In our family, if a person hasn't paid lobolo they're not considered to be the son-in-law of the family and the daughter isn't taken as a daughter-in-law of the other family.,

Furthermore, some respondents expressed the belief that in being recognised as a legitimate spouse within a customary marriage, one was entitled to seek help from their families when experiencing marital conflict. For example, one respondent stated that 'I have the right to go there to complain if I feel it's beyond my control. I have a right to go home and complain...'

Thus, the respondents perceived the family as a forum of dispute resolution that could be turned to for support and assistance in turbulent times of marriage. The above response also indicates the stage at which it is perceived to be appropriate to turn to the family collective for support in a marital conflict. That is, when such a conflict moves beyond the 'control' of the aggrieved spouse or spouses and resolution cannot be achieved from within the married couple. This was elaborated upon by respondents during their follow-up interviews: 'If we have conflicts or problems that we cannot discuss as a couple, then I go back to my uncle or my dad and I tell them about the problems I am facing back home.'

Furthermore, many of the respondents expressed in their follow-up interviews that either the family or the church (if a couple is part of a church community) should be turned to first when marital disputes could not be resolved by a couple: 'Families and pastors should be the first people that you consult with.'

In addition to providing a forum for dispute resolution to married couples, the respondents perceived the family as having a reconciliatory role when fulfilling this function. In other words, the family collective was perceived as having the task of trying to reconcile a couple who had turned to them for assistance with a

\footnotetext{
${ }^{1}$ The terms 'son-in-law' and 'daughter-in-law' are not conventionally used in describing relationships under customary law. As the interviews were conducted in Xhosa and later translated into English, it is unclear whether such terminology was originally used by the respondent or whether it was used by the translator. For the purpose of clarifying the idea conveyed within the quote, such terminology has been retained.
} 
marital dispute. In commenting on what happens when a marital dispute moves beyond the control of a spouse, one respondent commented that: 'My dad would call his family. They would sit down and see if they can save this marriage.'

The perceptions highlighted above were held by many of the respondents. Thus, the findings could indicate normative agreement about who should be turned to first when couples cannot resolve marital problems. Furthermore, such findings also point towards the normative roles that families are perceived to play in marital dispute resolution. However, it is important to note that such norms only seem to apply to customary marriages for which lobolo has been negotiated and transferred. Where this has not been done in a customary marriage, it seems that the family collective becomes hesitant to aid in the resolution of marital conflicts or problems. In such cases, the family collective is not turned to for assistance with the resolution of marital disputes because the couple aren't recognised as being legitimately part of both families. Instead, assistance is sought out from outside their families: 'The family members don't give help because they will not recognise him as their son-in-law so the couple will go and find help from other people who aren't part of the family.'

\section{State courts as a forum of dispute resolution: moving beyond the point of reconciliation}

Two vignettes, which were centred on conflicts associated with the exit out of marriage, were presented to the 39 married respondents during their initial interviews. The first of these vignettes concerned the division of matrimonial property upon the dissolution of a customary marriage. The vignette focused on a couple who had married under customary law and in community of property. The conflict that was presented to the respondents in the vignette arose due to the husband who wanted to leave the marriage but not share his property with his wife upon doing so. The second of these vignettes concerned the matter of child custody and maintenance after a divorce from a customary marriage had been granted by a state court. In this vignette, a husband had paid lobolo for his wife but after a few years of marriage, the couple obtained a divorce through court proceedings. The conflict that was presented to the respondents in the vignette was based upon the husband seeking custody of the couple's children even though it had been awarded to the children's mother by the court. The respondents were told that the husband had decided to stop financially maintaining his children until the mother gave up custody of them. In both vignettes, the respondents were asked to advise the female vignette characters on what they should do in their respective situations. 
In practice, these disputes, which are associated with the exit out of customary marriage, are said to have prejudicial outcomes for women. Such women are often left without a share of matrimonial property and retain primary care of the marital children without receiving financial support from their spouses after the dissolution of their customary marriages (Burman, 1987; Mamashela and Xaba, 2003). The abovementioned vignettes offered an insight into which forums of dispute resolution the respondents perceived should be turned to for assistance with such conflicts. In both vignettes, the overwhelming majority of respondents (30 out of 39 respondents in both vignettes) reflected the perception that the female vignette characters should turn to the state judicial system for support in the resolution of these disputes. None of the respondents, when responding to either vignette, perceived that family or other traditional forums of dispute resolution should be turned to for assistance in these disputes.

In the vignette that was discussed in the previous section (regarding the payment of lobolo upon entry into customary marriages), it was noted that family involvement in marital disputes was emphasised by the majority of respondents as being important. Why was it that the same emphasis was lacking in the responses to the vignettes which dealt with disputes relating to the exit from customary marriages?

As discussed in the previous section, the respondents perceived family dispute resolution forums as playing a reconciliatory role in the resolution of marital disputes. It is argued here that, in presenting the respondents with conflicts relating to the exit out of customary marriage, the respondents might have perceived the marital disputes in the two vignettes as already being beyond the point of reconciliation, and thus, beyond the point of familial assistance. In the first vignette, the male character had already decided to exit his customary marriage. In the second vignette, divorce had already occurred. Thus, in understanding the responses to the two vignettes, it is not necessarily that the respondents rejected the family as a forum for dispute resolution in marital conflict.

Rather, the findings could point towards an implicit normative agreement among respondents about the point at which familial support in marital disputes should end. That is, when a marital dispute moves past the point of reconciliation between spouses. This was highlighted by some respondents during their followup interviews. In speaking about what happens when families are unable to reconcile married couples, one respondent noted: 'Well they [the family] try to put them [the married couple] together but if it's beyond their ability, they allow them to live their lives.' 
As will be highlighted in the following section, when attempts at reconciliation fail many women are left to negotiate the exit out of their customary marriages with their husbands. This often renders women vulnerable to the unequal power relations between spouses. As has been noted, this can result in economically prejudicial consequences for women and children upon marital breakdown. The respondents reflected an awareness of such occurrences. Thus, the findings from the vignettes could be indicative of normative perceptions about when support from the state in marital disputes should begin to be sought. As one respondent noted in a follow-up interview: 'The court should be the last place you go to when you feel like you are overpowered, can't handle it and the situation is beyond your strength.'

Why did the married respondents perceive that the state should be turned to for assistance by the female vignette characters in their respective disputes? The remainder of this section will demonstrate that there was an implicit perception, held by some respondents, that when spouses are left to deal with their disputes on their own, unequal power relations between spouses can negatively impact on the outcomes of such disputes. Furthermore, it will be argued that the respondents perceived that seeking assistance from the state would protect women from inequitable outcomes in disputes caused by the unequal power relations which exist between spouses.

In responding the each of the divorce-related vignettes, many of the respondents reflected the perception that the male characters had spousal or parental responsibilities which they were obligated to fulfil. In the vignette which focused on the issue of custody and maintenance of children after divorce, many of the respondents expressed that the husband in the vignette was responsible for financially maintaining his children. This responsibility was perceived to exist regardless of whom had custody of the children after the dissolution of the customary marriage: 'The father has to maintain his children...they're his. No one else will maintain them, even if they are not in his custody.'

In the vignette which dealt with the division of matrimonial property upon exit out of a customary marriage, many respondents expressed the view that, in agreeing to marry in community of property, a binding obligation was placed upon both spouses to share their property in the event of a divorce: 'Once you are in community of property, you are committing and tying yourself.'

Furthermore, in the responses to both vignettes, the perception was implicitly reflected by some of the respondents that there could be unequal power relations between the spouses in the vignettes. These unequal power relations were perceived as being able to negatively influence the outcome of the disputes, should the female vignette characters attempt to enforce their spouses' 
obligations by themselves. For instance, in the vignette which dealt with the division of matrimonial property, one respondent commented that, if she were in the same position, she would prefer her husband to take his property without the division thereof: If it were for me, I would let him take his things and I can have what is mine. The reason why I am saying this [is because] I don't want to be suffering. And the reason is being him; because he has made his decision and I am not going to change it.'

The above quote illustrates the perceived unequal power relations between spouses in such conflicts. Due to these unequal power relations, a wife's pursuit to enforce the performance of her husband's legal obligations on her own was perceived by the respondent as being in vain for two reasons. Firstly, the respondent perceived that this pursuit would likely result in the wife 'suffering' from emotional distress or other forms of trauma due to the conflict with her husband. Secondly, it was also perceived that it would be unlikely that such efforts would bring about any changes in the situation as the husband's decision on the matter would still be enforced.

In relation to both vignettes, many respondents expressed the perception that the state could be turned to for assistance in enforcing the performance of such obligations against uncooperative spouses. This was perceived as a way of reducing interpersonal adversarialism between the spouses and preventing the unequal power relations between them from influencing the outcome of the dispute. Thus, in responding to the vignette relating to the division of matrimonial property, the perception was expressed that one way in which the woman could avoid the abovementioned 'suffering' and conflict, would be to turn to the state legal system for assistance and protection: 'He got married saying these things belong to them so Nolundi should take steps to go to court...so that they can resolve this issue for her. I don't even see the reason for her to be fighting with him because they got married in community of property.'

Similarly, relating to the vignette concerning the custody and maintenance of children, many of the respondents expressed the perception that state courts could be turned to, to enforce the performance of the parental responsibility in question: 'There is a very easy way for Mrs. Zimande to resolve this; it's to go to the magistrates court and for the magistrate to force Mr. Zimande to pay maintenance for his children.' Moreover, in turning to the state for assistance to enforce the performance of such a parental responsibility, the woman in the vignette would be protected from prejudicial outcomes resulting from the unequal power relations between spouses: 'Mrs. Zimande should go to the law because that is where she will be defended.' 
The findings set out above highlight why it was perceived that state courts should be turned to for assistance in marital conflicts involving the exit out of customary marriages. The perception was expressed that, the possibility of women being able to obtain equitable outcomes to such disputes on their own, would be unlikely. This was due to the unequal power relations that were perceived to exist between married spouses. State courts on the other hand, were perceived to be powerful due to their ability to enforce the performance of spousal and parental obligations against uncooperative spouses. Furthermore, due to this ability, state courts were perceived to be able to provide a forum for dispute resolution which protects women from highly adversarial and prejudicial conflicts with their husbands. Consequently, state courts were perceived to be forums for dispute resolution in which the unequal power relations between spouses would not have an influence on the outcome of the marital conflict, thereby ensuring that women were able to obtain equitable resolutions to their disputes.

\section{Additional forums of dispute resolution}

The perceptions discussed in the preceding section were held by the majority of the respondents in their initial and follow-up interviews. However, it is worth noting for the purposes of discussion later on in the paper that some respondents perceived that other forums should be turned to for assistance with the resolution of marital disputes.

In a follow-up interview, one respondent expressed that people who were part of a church community usually turned to their churches for assistance before turning to their families: 'To people who are religious, it is necessary for the church leaders to intervene. Then the families can intervene. It doesn't usually happen that when the church leaders have intervened that the problem doesn't get solved.'

The above response highlights the perception that religious dispute resolution forums also have a reconciliatory role in marital dispute resolution. The same respondent also narrated a story about a couple, who after failing to achieve reconciliation through their families, turned to the local ward counsellor in the area for assistance with their dispute:

'Both families intervened by they were not able to resolve the issues because it became apparent that the wife's family was taking her side and the husband's family was taking his side. So no consensus was reached and the problem was not solved. There was no way forward so they went to the ward counsellor in order to have a way forward.' 
According to the respondent, the ward counsellor, with success, also aimed to reconcile the couple. 'The ward counsellor, what he did in that case is that he tried to get them to forgive each other and get them back together...This couple is now on the road to reconciliation.'

In the vignette relating to the division of matrimonial property, some respondents reflected the view that the female vignette character should turn to the police to effect the division of marital property. Other respondents expressed that the female vignette character should turn to Home Affairs for assistance. It was perceived that Home Affairs would be able to divide the property, or at the very least, offer advice to the female vignette character on what course of action she should take.

Lastly, one respondent reflected the perception that the female vignette character would be assisted by FAMSA:

'[She should go] to report at Home Affairs. They are going to check if she is really married and they will send her to FAMSA. At FAMSA she would state her problems and that is where she is going to get it resolved.'

FAMSA (Families South Africa) is an NGO that has branches throughout South Africa (FAMSA, 2010). Among other services, it aims to provide divorce counselling and mediation services to under- and unserviced communities in South Africa (FAMSA, 2010).

\section{Practices relating to the exit out of customary marriages and the dispute resolution forums turned to for assistance}

As previously mentioned, this section is based upon the findings drawn from data that was collected from 17 women ('the divorcees') who had experienced the dissolution of their customary marriages (Himonga and Moore, 2013). The data collected from these interviews shed light on how the system of dispute resolution forums was used by women when they experienced marital breakdown.

In all except one case, when marital conflicts could not be resolved by couples, each woman first turned to their family collectives for support in their respective marital conflicts (Himonga and Moore, 2013). This indicates that the normative 
perceptions held by the married respondents, as highlighted in the preceding section, matched the practices of the divorcees. However, none of these women were able to achieve reconciliation with their spouses through the assistance of their families. Despite the widespread perception that state courts should be approached for support when reconciliation through the family fails, only 3 out of 17 women experienced the dissolution of their customary marriages in state courts (Himonga and Moore, 2013). Two of these three women initiated divorce proceedings in state courts, while the other woman was served divorce papers by her husband who had initiated the process.

Despite the recognition afforded to traditional leaders by the RCMA to mediate marital disputes, only two women turned to traditional leaders for support in their marital breakdowns after mediation with their families failed. The two women who did approach traditional leaders did not do so to seek assistance with the mediation of their marital conflicts. Instead, the traditional leaders were approached by the women to inform them of the circumstances under which their marriages had broken down. The women also wanted to make their grievances publically known, in order to protect their future interests (Himonga and Moore, 2013).

The remaining 14 women, who failed to achieve reconciliation through their families and who did not turn to state courts for assistance, were left in economically vulnerable positions upon the dissolution of their customary marriages. This was due to a number of factors. Firstly, it was found that in the majority of cases, equitable divisions of the matrimonial property had not been effected despite the majority of women being married in community of property (Himonga and Moore, 2013). The husbands often retained possession of the matrimonial property upon desertion, while the wives were left with only their personal possessions. In such cases, it was reported that the husbands were the sole decision makers regarding the property that their wives could retain after the dissolution of their marriages. Secondly, 14 out of the 17 divorcees remained the primary caretakers and custodians of the marital children after desertion. Most of the divorcees did not receive child maintenance or any other forms of financial support from their ex-husbands. In the few cases that child maintenance was paid, such payments were often irregular and insufficient (Himonga and Moore, 2013). This rendered the women without means of support for their children for extended periods of time. 


\section{The shortcomings within South Africa's system of dispute resolution forums}

It has been argued that South Africa, in being a legal pluralist state, has multiple forums of dispute resolution that can be approached for support in marital conflict. The research conducted by Higgins et al. (2007) and Griffiths (1997) indicated that there was a normative sequence in which different dispute resolution forums were approached by people in the legal pluralist contexts of South Africa and Botswana. The findings that were discussed, which related to the perceptions held by married respondents about dispute resolution forums, supported the research conducted by these authors. It was widely perceived by the 39 married respondents that the family collective should be the first source of support approached for assistance when experiencing marital conflict. If reconciliation or resolution within this forum is not achieved, many respondents perceived that state courts should then be turned to for assistance.

The findings, which outlined the experiences of women who underwent the dissolution of their customary marriages, were of concern. It was found that the family was not only the primary, but also often the sole forum of dispute resolution that was approached by the divorcees for assistance in their marital conflicts (Himonga and Moore, 2013). There could be many instances in which the family collective is able to reconcile couples and help them to resolve their marital problems. However, the experiences of the divorcees highlight what happens when resolution or reconciliation through the family fails. Despite the widespread perception that women should turn to state courts for assistance when reconciliation fails, the majority of the divorcees did not do so in practice (Himonga and Moore, 2013). Thus, most of the women did not obtain satisfactory support from either their families or state courts. Consequently, the majority of the divorcees were left without assistance to negotiate with their husbands the terms upon which their marriages ended. This exposed them to the operation of unequal power relations and left them in economically prejudicial positions upon the dissolution of their customary marriages (Himonga and Moore, 2013). These challenge the objectives of the RCMA and are arguably similar to the experiences of the women who underwent the dissolution of their customary unions under the Black Administration Act. Furthermore, these findings highlight that there are shortcomings or 'cracks' within South Africa's system of dispute resolution forums. As a consequence of these shortcomings, there are women who are placed in vulnerable positions upon the dissolution of their customary marriages.

What are the shortcomings within South Africa's system of dispute resolution forums? In comparing the perceptions of the married respondents with the 
experiences of the divorcees, some of these shortcomings become more apparent. As previously mentioned, the married respondents perceived that state courts should be approached for assistance when reconciliation through the family fails. However, in practice, when reconciliation failed, the majority of the divorcees did not turn to state courts for support (Himonga and Moore, 2013). In considering the above findings, the question arises as to why the state courts were not approached by the majority of the divorcees when they failed to obtain satisfactory outcomes through their families. There is a large body of research which has argued that structural constraints exist, which can prevent rural women from accessing state dispute resolution forums (Mamashela and Xaba, 2003; Himonga, 2005; Himonga and Moore, 2013). Thus, in attempting to understand why state courts were not turned to for assistance by the rural divorcees it would not be unreasonable to suggest that they may have experienced the operation of such constraints. That is, that they may have lacked information about the RCMA and the rights which it conferred to them (Mamashela and Xaba, 2003). Or, that they were not aware of the matrimonial property regimes which applied to their marriages and the consequences thereof (Himonga and Moore, 2013). Furthermore, they could have faced geographical or financial constraints which limited their access to the upper courts to initiate divorce proceedings (Himonga, 2005). These structural constraints are shortcomings within South Africa's system of dispute resolution forums, in that they limit access to the support provided by the state dispute resolution forums.

Secondly, although the RCMA recognised the ability of traditional leaders and others authorised under customary law to mediate disputes, the married respondents did not perceive that this forum should be turned to for assistance in conflicts associated with the dissolution of customary marriages. Nor was this forum of dispute resolution utilised by the divorcees when they underwent the dissolution of their customary marriages (Himonga and Moore, 2013). This could point towards another shortcoming within the system of dispute resolution forums in that there is a forum of dispute resolution available to married couples but that it is not being used, or perceived that it should be used. The reasons for this are unclear. Additional research is required to investigate what roles traditional leaders currently play in marital dispute resolution. Moreover, further research is required to explain the perceptions and practices of the married and divorced respondents in relation to traditional leaders.

As reflected through the provisions of the RCMA, the state has committed to ensuring gender equality upon the dissolution of customary marriages. The state has attempted to do this by offering support to married couples, at the point of marital breakdown, in state courts. However, as the findings from the divorcees suggest, state courts are not always being accessed for support in the dissolution of customary marriages. Furthermore, as was highlighted, this has meant that 
gender equality is not achieved in all customary marriage dissolutions. Thus, one might ask whether the state is providing support to couples, married under customary law, at too late of a point in marital breakdown. This is another possible shortcoming within South Africa's system of dispute resolution forums. That is, other than at the point of exit from customary marriages in state courts, no additional support is provided by the state to married couples experiencing marital breakdown. Could the state being doing more to ensure that women are not placed in economically prejudicial positions in the event of the dissolution of their customary marriages?

There are two possible courses of action that could help remedy the aforementioned shortcomings within the system of dispute resolution forums in South Africa. Firstly, steps should be taken by the state to address the abovementioned structural constraints. There are a number of ways in which these constraints can be addressed. It has been argued that people often lack of awareness about the RCMA, the matrimonial property regimes that apply to their customary marriages and the consequences of such legislation and property regimes (Mamashela and Xaba, 2003). As previously highlighted, some of the married respondents perceived that Home Affairs and the South African Police Service could be turned to for assistance with the resolution of marital conflicts associated with the exit from customary marriages. Although such perceptions indicate a certain amount of 'institutional confusion' (Himonga and Moore, 2013: 120), the state could empower actors within Home Affairs and the Police Service to provide people with the correct information regarding the RCMA and its consequences. Moreover, the state could make more information available at Home Affairs offices, regarding how the consequences of the matrimonial property regimes could be enforced. This would inadvertently involve information on how to access the judicial system.

Moreover, the state could further empower traditional leaders to provide information or advice relating to how the RCMA provisions are to be enforced in the event of marital breakdown. Such actors could, when mediation fails, provide spouses with information regarding the consequences of the matrimonial property regime applicable to their marriage or how to initiate court proceedings. However, using these actors could be problematic given their reported bias towards reconciliation and retention of marriage instead of divorce (Higgins et al., 2007, Himonga and Moore, 2013). Furthermore, it is important to note that such an initiative would only be useful once further research has been conducted to explain the reasons for the perceptions and practices of the respondents in relation to traditional leaders.

It has also been argued that the financial costs of litigation and court proceedings would prevent women from turning to state courts for assistance 
(Himonga, 2005). The Department of Justice and Constitutional Development have, aimed to increase access to justice through introducing mediation procedures, in relation to civil matters, that can be utilised prior to the recourse of ordinary trial proceedings in Magistrate's Courts (South African Association of Mediators, 2013) ${ }^{2}$. Mediation is argued to be more cost effective and speedier than ordinary court proceedings. The Mediation Rules for the Magistrate Court, which came into force in March 2014, makes provision for mediation prior to the recourse to ordinary legal proceedings (Department of Justice and Constitutional Development, 2014). However, these rules stipulate that the parties to the mediation will bear the costs of the mediator's fees. This is problematic in that many of those who are in need of state support in the resolution of their customary marriage conflicts will often be unable to afford such fees (Law Society of South Africa, 2011). Thus, this would do little to improve access to justice. In order to remedy this, it has been suggested that the costs of court-based mediation should be covered by the state to ensure that impoverished people are able to enter into mediation and have their marital disputes resolved in this manner (Law Society of South Africa, 2011). It must be noted that the Mediation Rules would still only provide assistance to couples when they turn to the state judicial system for assistance in the dissolution of their customary marriages. Again, one could argue that this form of support is still not provided early enough in the marital breakdown process.

This leads to the second course of action that could be adopted by the state to remedy the abovementioned shortcomings in the country's system of dispute resolution forums which would involve providing additional mechanisms of support to married couples at an earlier stage in marital breakdown. Such additional mechanisms could include counselling or mediation services. It could also involve aiding in the expansion and capacity of existing services provided by NGOs and organisations like FAMSA, which aim to provide support to married couples prior to the actual dissolution of their marriages.

\section{Conclusion}

This paper has highlighted that South Africa has a system of dispute resolution forums which are available to those who experience marital conflict and breakdown in customary marriage. However, it has been demonstrated that there are serious shortcomings within this system. There are structural constraints which arguably limit or prevent access to state courts by those who seek support in the dissolution of their customary marriages. Furthermore, it has been argued that there is insufficient support offered by the state to couples who experience

\footnotetext{
${ }^{2}$ The Mediation Rules as applying to the High Court have not yet been finalised.
} 
the breakdown of their customary marriages. These shortcomings have contributed to some rural women being placed in economically prejudicial positions upon the dissolution of their customary marriages.

The paper has also provided possible solutions that could be adopted to remedy the abovementioned shortcomings. It is by no means suggested that they are the only solutions that could remedy the shortcomings within the system of dispute resolution forums. It must also be noted that these solutions would require immense financial and administrative resources from the state. However, these costs need to be weighed against the need to ensure that gender equality is enjoyed by those who experience the dissolution of their customary marriages. 


\section{References}

Banda, F. 2006. Women, law and human rights in Southern Africa. Journal of Southern African Studies, 32(1): 13-27.

Bennett, T.W. 2004. Concepts and Theory. In Customary Law in South Africa. Cape Town: Juta and Company Ltd.

Burman, S. 1987. Marriage break-up in South Africa: holding want at bay? International Journal of Law and the Family, 1(2): 206-247.

Department of Justice and Constitutional Development. 2014. Amendment of Rules Regulating the Conduct of the Proceedings of the Magistrates Courts of South Africa. Government Notice no. 37448, 18 March 2014. Available at: http://www.justice.gov.za/legislation/notices/2014/2014-03-18-

gg37448_rg10151_gon183-rules-mc.pdf [Accessed 2014, June 12].

Deveaux, M. 2003. Liberal constitutions and traditional cultures: the South African Customary Law Debate. Citizenship Studies, 7(2): 161-180.

FAMSA. 2010. Families South Africa. Available at: http://mzansiitsolutions.co.za/famsaorg/?q=node/48 [Accessed 2014, February 12].

Finch, J. 1987. The Vignette Technique in Survey Research. Sociology, 21(1): 105-114.

Griffiths, A. 1997. Pregnancy and Marriage: The World of Negotiation and Dispute. In In the shadow of marriage: gender and justice in an African community. Chicago: The University of Chicago Press, pp. 106-133.

Higgins, T. E, Fenrich, J. \& Z. Tanzer. 2007. Gender equality and customary marriage: Bargaining in the shadow of post-apartheid legal pluralism. Fordham International Law Journal, 30(6): 1653-1708.

Himonga, C. 2005. The advancement of African women's rights in the first decade of democracy in South Africa: The reform of customary law in marriage and succession. Acta Juridica, 82-107.

Himonga, C. 2007. Marriage. In Du Boise, F. (ed.) Wille's Principles of South African Law ( $9^{\text {th }}$ edition). Cape Town: Juta and Company Ltd., pp. 254-262. 
Himonga, C. \& Moore, E. 2013. The Recognition of Customary Marriages Act and Bhe v Khayelitsha Magistrate: A socio-legal study [Unpublished Draft Preliminary Findings]. National Research Foundation Chair in Customary Law.

Law Society of South Africa. 2011. Comments by the Law Society of South Africa (LSSA) on the proposed mediation rules. Available at: http://molony.co.za/wp-content/uploads/2012/03/LSSA-SUBMISSIONS-ONMEDIATION-RULES-31-OCTOBER-2011.pdf [Accessed 2014, February 12].

Mamashela, M. \& T. Xaba. 2003. The Practical Implications and Effects of the Recognition of Customary Marriages Act No. 120 of 1998. Research Report No. 59. Available at: http://sds.ukzn.ac.za/files/rr59.pdf [Accessed 2014, February 12].

Marias, H. 2011. The making of a polarised society. In in South Africa pushed to the limit: The political economy of change. Cape Town: UCT Press, pp. 7-27.

Mbatha, L. 2005. Reflection on the Rights created by the Recognition of Customary Marriages Act. Agenda: Empowering women for gender equityVolume Special Focus: 42-47.

Mbatha, L., Moosa, N. \& E. Bonthuys. 2007. Culture and Religion. In Bonthuys, E. \& C. Albertyn (eds.) Gender, Law and Justice. Cape Town: Juta \& Co., pp. 158-194.

Monareng, K. \& Zounmenou, M. 2007. Black women, are you aware that you are concubines? The legal implications of South African family law. Agenda: Empowering women for gender equity, 21(71): 122-129.

Nhlapo, T.1995. African customary law in the interim constitution. In Libenberg, S. (ed.) The Constitution of South Africa from a Gendered Perspective. Claremont: Community Law Centre, University of the Western Cape, pp. 157-166.

Posel, D. 1995. State, Power and Gender: Conflict over the registration of African customary marriage in South Africa: 1910-1970. Journal of Historical Sociology, 8(3): 223-256. 
Sloth-Nielsen, J. 2010. The Amendment of the Jurisdiction of the Regional Courts Act, 2008: the Good, the Bad and the Objectionable. Available at: http://www.millerdutoitcloeteinc.co.za/familylawcapetownimg/Conf2011/Conf2 011/Paper\%20-\%20Sloth-Nielssen\%20-\%201.pdf [Accessed 2014, February $13]$.

South African Association of Mediators. 2013. Media Statement: July 2013. Available at:

http://www.saam.org.za/uploads/SAAM\%20Media\%20Statement\%20July\%202 013.doc [Accessed 2014, February 12]. 